\title{
Pulmonary arterial dysfunction in insulin resistant obese Zucker rats
}

\author{
Javier Moral-Sanz, Carmen Menendez, Laura Moreno, Enrique Moreno, Angel Cogolludo and \\ Francisco Perez-Vizcaino*
}

\begin{abstract}
Background: Insulin resistance and obesity are strongly associated with systemic cardiovascular diseases. Recent reports have also suggested a link between insulin resistance with pulmonary arterial hypertension. The aim of this study was to analyze pulmonary vascular function in the insulin resistant obese Zucker rat.

Methods: Large and small pulmonary arteries from obese Zucker rat and their lean counterparts were mounted for isometric tension recording. mRNA and protein expression was measured by RT-PCR or Western blot, respectively. $\mathrm{K}_{V}$ currents were recorded in isolated pulmonary artery smooth muscle cells using the patch clamp technique.

Results: Right ventricular wall thickness was similar in obese and lean Zucker rats. Lung BMPR2, $\mathrm{K}_{\mathrm{v}} 1.5$ and 5-HT $2 \mathrm{~A}$ receptor mRNA and protein expression and $K_{V}$ current density were also similar in the two rat strains. In conductance and resistance pulmonary arteries, the similar relaxant responses to acetylcholine and nitroprusside and unchanged lung eNOS expression revealed a preserved endothelial function. However, in resistance (but not in conductance) pulmonary arteries from obese rats a reduced response to several vasoconstrictor agents (hypoxia, phenylephrine and 5-HT) was observed. The hyporesponsiveness to vasoconstrictors was reversed by L-NAME and prevented by the iNOS inhibitor $1400 \mathrm{~W}$.

Conclusions: In contrast to rat models of type 1 diabetes or other mice models of insulin resistance, the obese Zucker rats did not show any of the characteristic features of pulmonary hypertension but rather a reduced vasoconstrictor response which could be prevented by inhibition of iNOS.
\end{abstract}

\section{Background}

Pulmonary arterial hypertension (PAH) is a progressive disease of poor prognosis characterized by vasoconstriction of pulmonary arteries (PA) and proliferation of pulmonary vascular endothelial and smooth muscle cells leading to increase vascular resistance and right heart failure with right ventricular hypertrophy as a hallmark $[1,2]$. These pathological events are influenced by genetic predisposition as well as environmental stimuli [1,3]. Bone Morphogenetic Protein Receptor 2 (BMPR2) gene mutations have been described in some $\mathrm{PAH}$ patients [4] and diminished expression of its encoded protein has also been shown in both human and animal models of PAH [5-8]. Additionally, endothelial dysfunction and increased 5-HT contractile response have been

\footnotetext{
* Correspondence: fperez@med.ucm.es

Departamento de Farmacologia, Facultad de Medicina, Universidad

Complutense de Madrid, 28040 Madrid. Spain and Ciber Enfermedades
} Respiratorias, CIBERES reported in PAH [9-11]. Several studies have reported the involvement of $\mathrm{K}_{\mathrm{V}}$ channels in controlling membrane potential of pulmonary artery smooth muscle cells (PASMC) and PA tone [12]. Moreover, it was reported the role of $\mathrm{K}_{\mathrm{V}} 1.5$ in the development of PAH as a result of mutation or downregulation of the channel $[13,14]$.

Obesity and insulin resistance have a worldwide increasing prevalence. Despite the fact that insulin resistance is strongly associated with systemic cardiovascular diseases $[15,16]$ the relationship with pulmonary vascular disease has been almost disregarded [17]. Recent reports have suggested that insulin resistance might also be associated with pulmonary hypertension in humans [18-20] and in the ApoE deficient mice [21]. In rats with type 1 diabetes, we have recently found pulmonary endothelial dysfunction associated to increased superoxide production and upregulation of the NADPH oxidase subunit $\mathrm{p} 47^{\text {phox }}[8]$. The Obese Zucker rat is a well establish model of obesity and insulin resistance

\section{Biomed Central}


associated to systemic vascular dysfunction [22-24]. Nonetheless, the pulmonary vasculature remains uncharacterized in this model. Therefore, the present study was designed to analyze the pulmonary markers of $\mathrm{PAH}$ including the pulmonary expression of key proteins of the disease, $\mathrm{K}_{\mathrm{V}}$ currents, vascular reactivity of PA, and right ventricular hypertrophy in obese Zucker rats compared to their lean Zucker littermates.

\section{Methods}

\section{Ethics statement}

The present investigation conforms to the Guide for the Care and Use of Laboratory Animals (National Institutes of Health Publication No. 85-23, revised 1996), and the procedures were approved by our institutional review board (Comité de Experimentación Animal, Universidad Complutense, 070208).

\section{Animals, tissues and reagents}

On the day of the experiment, male obese Zucker rats $(\mathrm{fa} / \mathrm{fa})$ and their littermates, lean Zucker rats $(\mathrm{fa} /-)$ (1718 weeks old) were weighed and sacrificed by cervical dislocation and exsanguination. Pulmonary arteries (PA) were dissected to obtain conductance and resistance intrapulmonary arteries. Smooth muscle cells were then enzymatically isolated from resistance intrapulmonary arteries [25]. Blood glucose was measured using a clinical glucometer (OneTouch Ultra) and insulin using an enzyme immunoassay. Hearts were excised, fixed with formol embedded in paraffin and cut into $1 \mathrm{~mm}$ cross sections, visualized in a microscope, photographed and analyzed using imageJ (Ver 1.41, NIH, USA). All drugs were from Sigma (Tres Cantos, Spain).

\section{Vascular reactivity}

Resistance (diameter $\sim 0.3-0.5 \mathrm{~mm}$ and length $\sim 2 \mathrm{~mm}$ ) and conductance (diameter $\sim 1-1.2 \mathrm{~mm}$ and length $\sim 3$ $\mathrm{mm})$ PA rings were mounted in Krebs solution at $37^{\circ} \mathrm{C}$ gassed with a $95 \% \mathrm{O}_{2}-5 \% \mathrm{CO}_{2}$ mixture in a wire myograph or in organ chambers respectively. After stretching to give an appropriate resting tension (equivalent to $30 \mathrm{~mm} \mathrm{Hg}$ as previously described [25] for resistance or $0.7 \mathrm{~g}$ for conductance arteries) each vessel was exposed to different vasoconstrictor agents to test the vascular response. The contractile responses were performed by cumulative addition and expressed as a percentage of the response to $80 \mathrm{mM} \mathrm{KCl}$. The endothelial function was estimated by the analysis of the relaxant response to cumulative addition of acetylcholine (ACh, $10^{-9}-10^{-}$ ${ }^{4} \mathrm{M}$ ) after precontraction with $10^{-7} \mathrm{M}$ phenylephrine in conductance arteries or with a concentration of phenylephrine titrated to induce a contraction $75 \%$ of the response to $\mathrm{KCl}$. Some experiments were carried out in the presence of the NOS inhibitor L-NAME. Hypoxia was induced by bubbling the Krebs solution with $95 \%$ $\mathrm{N}_{2}-5 \% \mathrm{CO}_{2}$ to achieve an oxygen concentration of 3-4\% (24 \pm 1 Torr) in the chamber as described [26].

\section{Electrophysiological studies}

Membrane currents were recorded using the whole-cell configuration of the patch clamp technique with an Axopatch 200B and a analog to digital converter Digidata 1322A (Axon Instruments, Burlingame, CA, U.S.A). pClamp version 9 software was used for data acquisition and analysis. Cells were superfused with an external $\mathrm{Ca}^{2}$ ${ }^{+}$-free Hepes solution $(2 \mathrm{ml} / \mathrm{min})$ and a $\mathrm{Ca}^{2+}$-free pipette (internal) solution containing (mmol/L): $\mathrm{KCl} 110, \mathrm{MgCl}_{2}$ 1.2, $\mathrm{Na}_{2} \mathrm{ATP} 5$, HEPES 10, EGTA 10, pH adjusted to 7.3 with $\mathrm{KOH}$. Patch pipettes (2-4 M $\Omega$ ) were constructed from borosilicate glass capillaries (GD-1, Narishige Scientific Instruments, Tokyo, Japan) using a programmable horizontal puller. Currents were evoked following the application of $200 \mathrm{~ms}$ depolarizing pulses from -60 $\mathrm{mV}$ to test potentials from $-60 \mathrm{mV}$ to $+60 \mathrm{mV}$ in 10 $\mathrm{mV}$ increments [27]. Hypoxia was induced by bubbling the solution with $\mathrm{N}_{2}$ as described [26].

\section{Protein expression}

Whole lungs were homogenated under reducing conditions in the presence of DTT, proteases and phosphatases inhibitors. Protein content was determined by BioRad DC Protein Assay Kit (Bio-Rad, Hercules, CA, USA) and equal amounts of proteins were loaded and subjected to electrophoresis on a SDS-PAGE (7.5-10\%) followed by a transference to a PVDF membrane (BioRad). Protein expression was quantified using primary antibodies anti- $\mathrm{K}_{\mathrm{V}} 1.5$ (Alomone, Israel, 1:200 dilution), anti-5 $\mathrm{HT}_{2 \mathrm{~A}}$ (BD Biosciencies, 1:250 dilution), anti- Bone Morphogenetic Protein Receptor 2 (BMPR2) (BD Biosciencies, 1:250 dilution), anti-eNOS (BD Biosciencies, 1:2500 dilution), anti-iNOS (Santa Cruz, CA, USA, 1:500 dilution), anti- $\beta$-actin (Sigma-Aldrich, Spain, 1:5000 dilution) and horseradish peroxidase conjugated secondary goat anti-mouse and anti-rabbit antibodies (Santa Cruz Biotech, CA, USA, 1:10000 dilution). Proteins were detected using ECL-Plus Western blotting reagents (Amersham, GE Healthcare, CT, USA) and analyzed using Quantity One (BioRad).

\section{Real time RT-PCR}

Total RNA was isolated and purified from resistance PA homogenates using RNeasy Mini kit (Qiagen, Hilden, Germany) and converted into cDNA using iScript cDNA synthesis kit (BioRad, Hemel Hempstead, UK). Real-time PCR was performed using a Taqman system (Roche Diagnostics, Mannheim, Germany) in the Genomic Unit of Universidad Complutense de Madrid. Specific primers were designed for rat $\mathrm{K}_{\mathrm{V}} 1.5$ (sense 5'- 
GGAAGAACAAGGCAACCAGA-3', antisense 5'-AG CTGACCTTCCGTTGACC-3'), iNOS (sense 5'-TTG GAGTTCACCCAGTTGTG-3', antisense 5'-ACATCGAAGCGGCCATAG-3'), eNOS (sense 5'-GGTATTTGATGCTCGGGACT-3', antisense 5'-TGTGGTTACA GATGTAGGTGAACA-3'), BMPR2 (sense 5'-CGGGC AGGATAAATCAGGA-3', antisense 5'-CAGGAAAGTAAATTCGGGTGA-3') and $\beta$-actin (sense $5^{\prime}$-GCCC TAGACTTCGAGCAAGA-3', antisense 5'-TCAGGCAGCTCATAGCTCTTC-3'). Data were normalized by the expression of $\beta$-actin.

\section{Statistical analysis}

Results are expressed as mean \pm s.e.m. Data for Western blots and RT-PCR were normalized by the expression of $\beta$ actin and expressed as a percentage of the values obtained in the lean rats. Individual cumulative concentrationresponse curves were fitted to a logistic equation. The negative logarithm of the molar concentration that causes $50 \%$ of the maximum response $\left(\mathrm{pD}_{2}\right)$ and the maximum response $\left(E_{\max }\right)$ were calculated for each ring. Statistical analysis was performed by comparing the lean and obese Zucker groups with an unpaired Student's $t$-test. Differences were considered statistically significant when $P<0.05$.

\section{Results}

Obese Zucker rats showed a final body weight $~ 30 \%$ higher than their lean littermates $(476 \pm 29$ vs $364 \pm 22$ g, respectively, $\mathrm{P}<0.01, \mathrm{n}=20$ for both groups). Non fasting blood glucose was not significantly different (128 \pm 13 vs $106 \pm 5 \mathrm{mg} / \mathrm{dL}$, respectively, $\mathrm{n}=13$ and 12) but insulin was strongly elevated ( $3.5 \pm 0.2$ vs $1.4 \pm 0.2 \mathrm{ng} /$ $\mathrm{ml}$, respectively, $\mathrm{n}=7$ for both groups).

\section{Heart wall thickness and BMPR2 expression}

No significant changes were found in the wall thickness of the right ventricle (RV), the left ventricle (LV) or the septum (S) from obese as compared with lean rats (Figure $1 \mathrm{~A})$. The RT-PCR analysis revealed no changes in mRNA transcription levels of BMPR2 gene in resistance PA (Figure 1B) and Western blots showed no significant changes in the whole lung protein expression of BMPR2 or in its heavier precursor (pro-BMPR2) (Figure 1C).

\section{$\mathrm{K}_{\mathrm{V}}$ currents and $\mathrm{K}_{\mathrm{V}} 1.5$ lung expression}

Similar cell capacitance $(17.8 \pm 1.1$ and $18.4 \pm 0.7 \mathrm{pF}$ in obese and lean rats, respectively), as a measure of the cell size, and similar $\mathrm{K}_{\mathrm{V}}$ current density (Figure $2 \mathrm{~A}$ ) were found in lean and obese PASMC. Moreover,

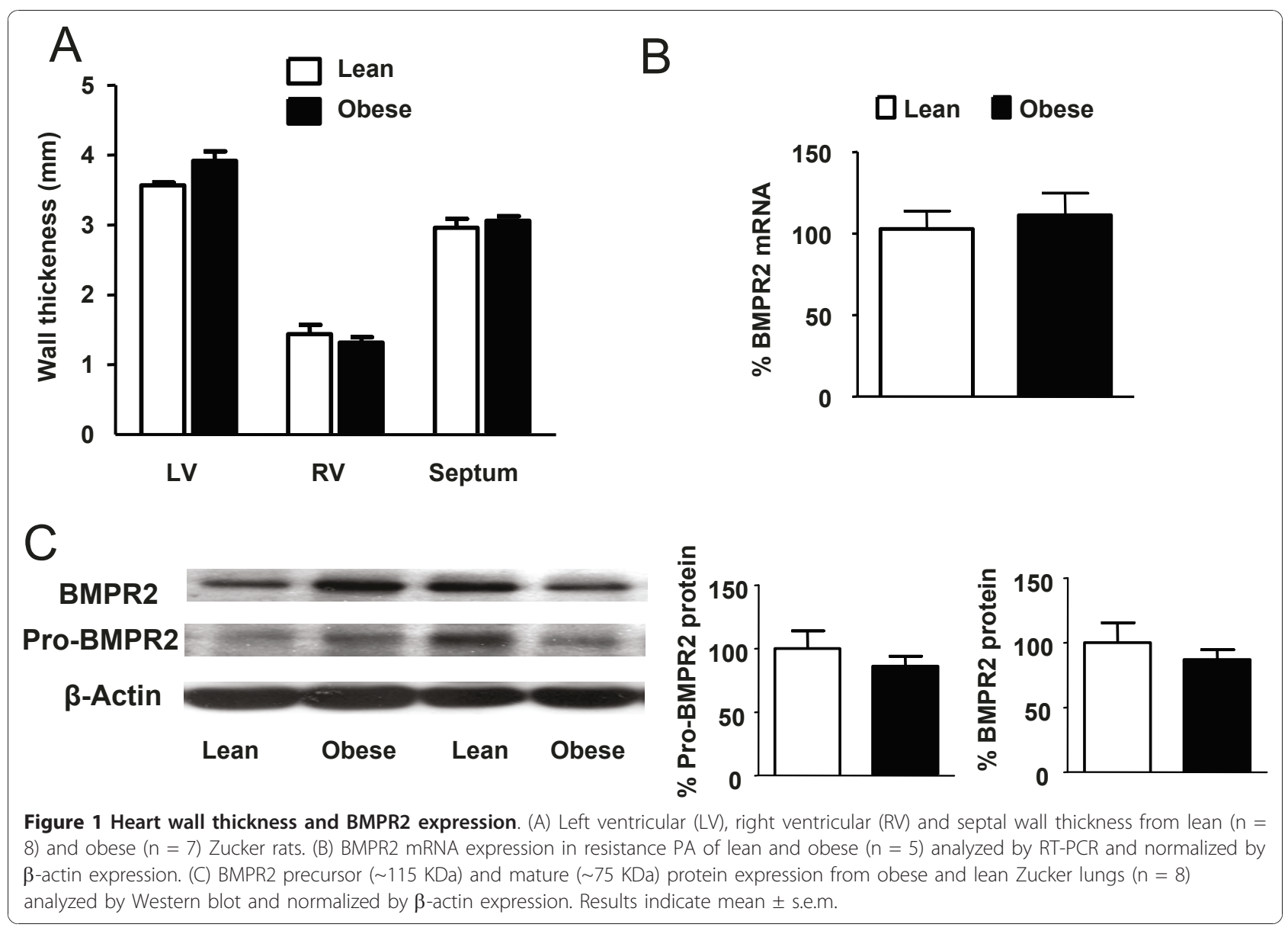


hypoxia induced a similar inhibition of $\mathrm{K}_{\mathrm{V}}$ currents in both strains (Figure 2B). In accordance with patchclamp data, no changes in $\mathrm{K}_{\mathrm{V}} 1.5$ mRNA transcription in resistance PA (Figure $2 \mathrm{C}$ ) or whole lung protein expression (Figure 2D) were found in obese as compared to lean rats.

\section{Endothelial function}

The endothelial function was tested in endothelium intact PA preconstricted with phenylephrine $\left(10^{-7} \mathrm{M}\right.$ in conductance arteries or a concentration titrated to induce a contraction $75 \%$ of the response to $\mathrm{KCl}$ in resistance $\mathrm{PA}$ ). Increasing concentrations of $\mathrm{ACh}$ induced a similar relaxant response in obese and lean rats in conductance arteries (Figure 3A). Resistance arteries from obese rats required higher concentrations of phenylephrine to achieve a tone similar to the lean ones $\left(5 \pm 2 \cdot 10^{-6} \mathrm{M}\right.$ vs $7 \pm 2 \cdot 10^{-7} \mathrm{M}$, respectively). The analysis of the concentration-response curves to ACh shows that there were not significant changes in the $E_{\max }$ values between groups in conductance $\left(E_{\max } 53 \pm\right.$ 7 vs $67 \pm 9 \%$, respectively) or resistance vessels ( $E_{\max } 59$ \pm 8 vs $66 \pm 4 \%$, respectively). Similarly, the concentration of ACh required for half-maximal relaxation in conductance $\left(\mathrm{pD}_{2}\right.$ values $6.4 \pm 0.1$ vs $6.2 \pm 0.2$, respectively) or in resistance vessels $\left(\mathrm{pD}_{2}\right.$ values $6.1 \pm 0.2$ vs $5.8 \pm 0.2$, respectively) was similar in both groups. In the presence of the NOS inhibitor L-NAME, similar concentrations of phenylephrine were required to induce $\sim 75 \%$ of $\mathrm{KCl}$ contraction in arteries from the obese and lean rats $\left(3 \pm 2 \cdot 10^{-8} \mathrm{M}\right.$ and $2 \pm 0.6 \cdot 10^{-8} \mathrm{M}$, respectively) but these concentrations were significantly lower than those required in the absence of L-NAME. Moreover, in the presence of this inhibitor, the relaxation to

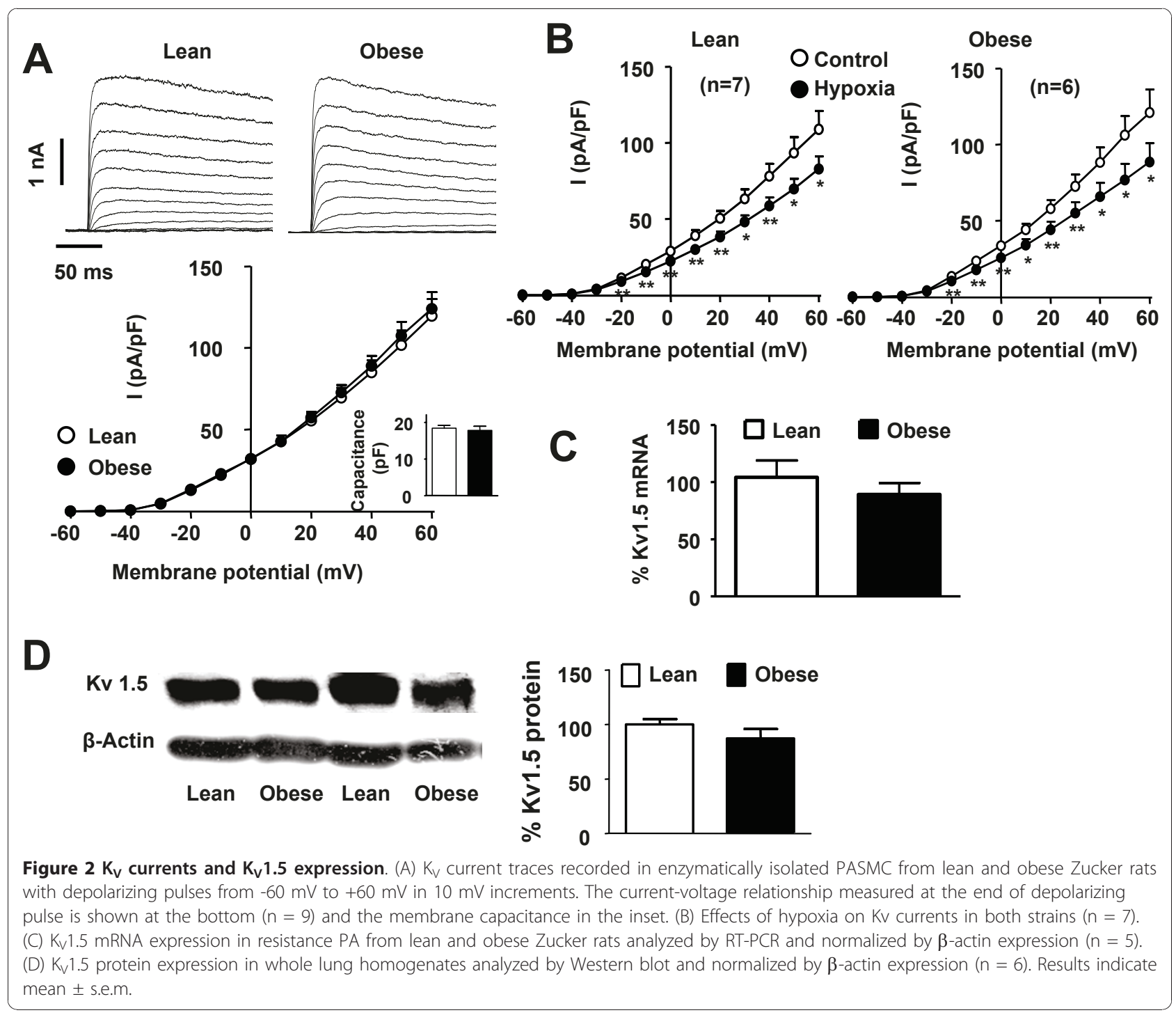




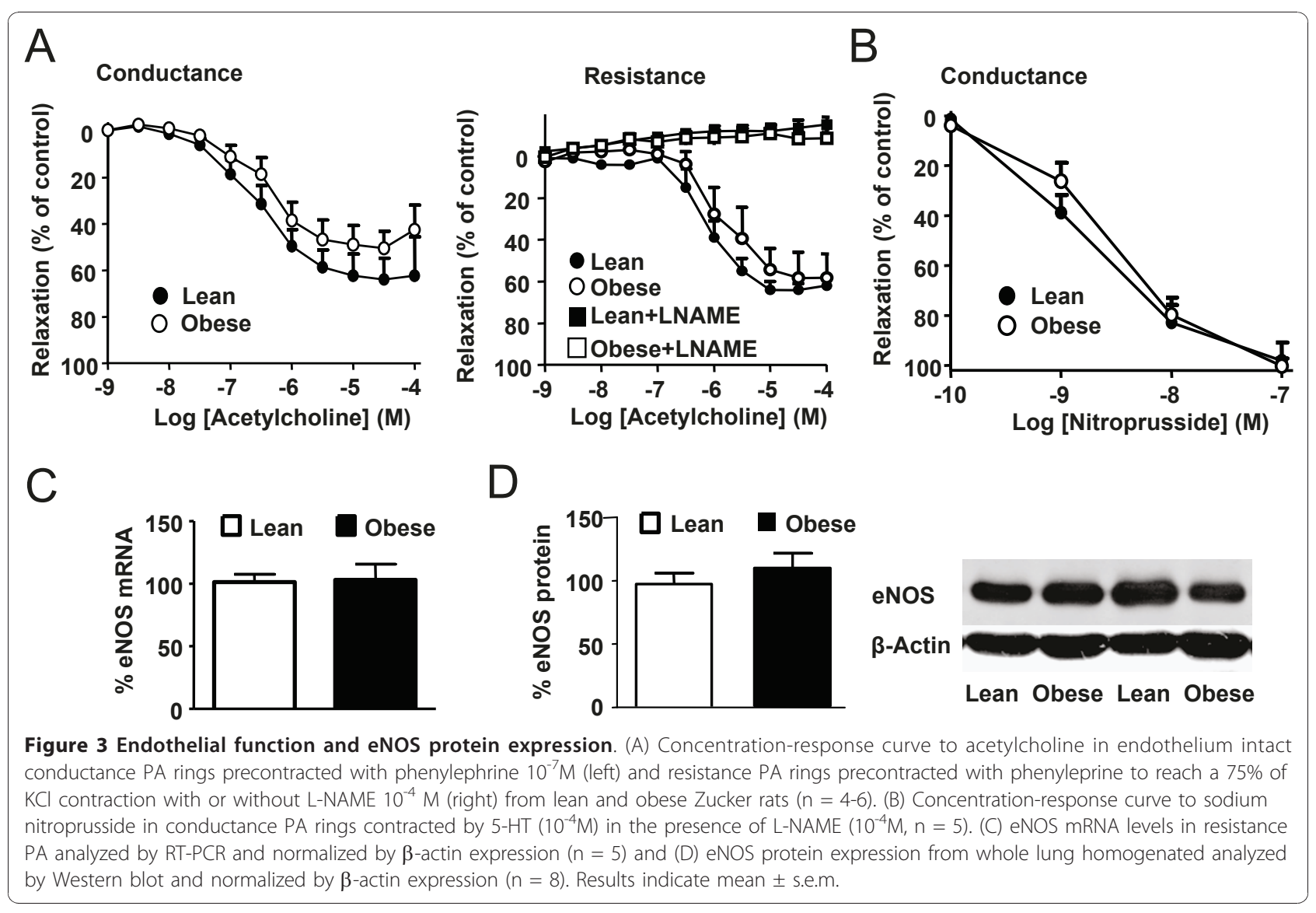

acetylcholine was completely abolished in both strains (Figure 3D). In addition, no changes were found in the response to the endothelium-independent vasodilator sodium nitroprusside in conductance PA (Figure 3B). Expression of eNOS mRNA in resistance PA (Figure $3 \mathrm{C}$ ) or eNOS protein in whole lung (Figure 3D) was also similar in both strains.

\section{Contractile responses in conductance PA}

Conductance pulmonary arteries were mounted in organ chambers to test the contractile response to $80 \mathrm{mM} \mathrm{KCl}$, phenylephrine and 5-HT. No changes were found in the responses to the vasoconstrictor agents $\mathrm{KCl}(80 \mathrm{mM})$ or phenylephrine $\left(10^{-7} \mathrm{M}\right)$ when both groups of rats were compared (Figure 4A). A similar concentration-response curve to 5-HT was also obtained in obese and lean rats (Figure $4 \mathrm{~B}, \mathrm{E}_{\max }$ and $\mathrm{pD}_{2}$ values are shown in Table 1).

\section{Contractile responses in resistance PA}

The contractile response to $80 \mathrm{mM} \mathrm{KCl}$ in resistance PA showed a significant reduction in obese compared to lean rats. Obese rats also evidenced a significant hyporesponsiveness to hypoxia, phenylephrine and 5-HT (Figure 5 and Table 1). We further investigated the response to the $5-\mathrm{HT}_{2}$ agonist $\alpha$-methyl-5-HT. This agonist also showed reduced vasoconstriction responses in PA rings from obese rats (Table 1). Western blot analysis of whole lung homogenates revealed no changes in the expression of $5-\mathrm{HT}_{2 \mathrm{~A}}$ receptors.

\section{Role of inducible NO synthase}

To test the role of $\mathrm{NO}$ in the vascular hyporesponsiveness observed in resistance PA, the NO synthase inhibitor L-NAME was added on top of the maximal response to 5-HT. L-NAME induced a further contraction in both arteries but it was significantly higher in the obese rats. Therefore, no differences were found in the final tone induced by 5 -HT plus L-NAME when both groups were compared, i.e. L-NAME restored the vascular hyporesponsiveness to 5-HT (Figure 6A). Interestingly, the incubation of the PA ring in the presence of the iNOS selective inhibitor $1400 \mathrm{~W}$ prevented the reduced response to 5-HT observed in the PA from obese rats and thus the responses were similar in obese and lean rats (Figure 6B). These results suggest that iNOS might be a source of the NO responsible of the vascular hyporesponsiveness in the obese rats. The levels of iNOS mRNA expression were highly variable in the 


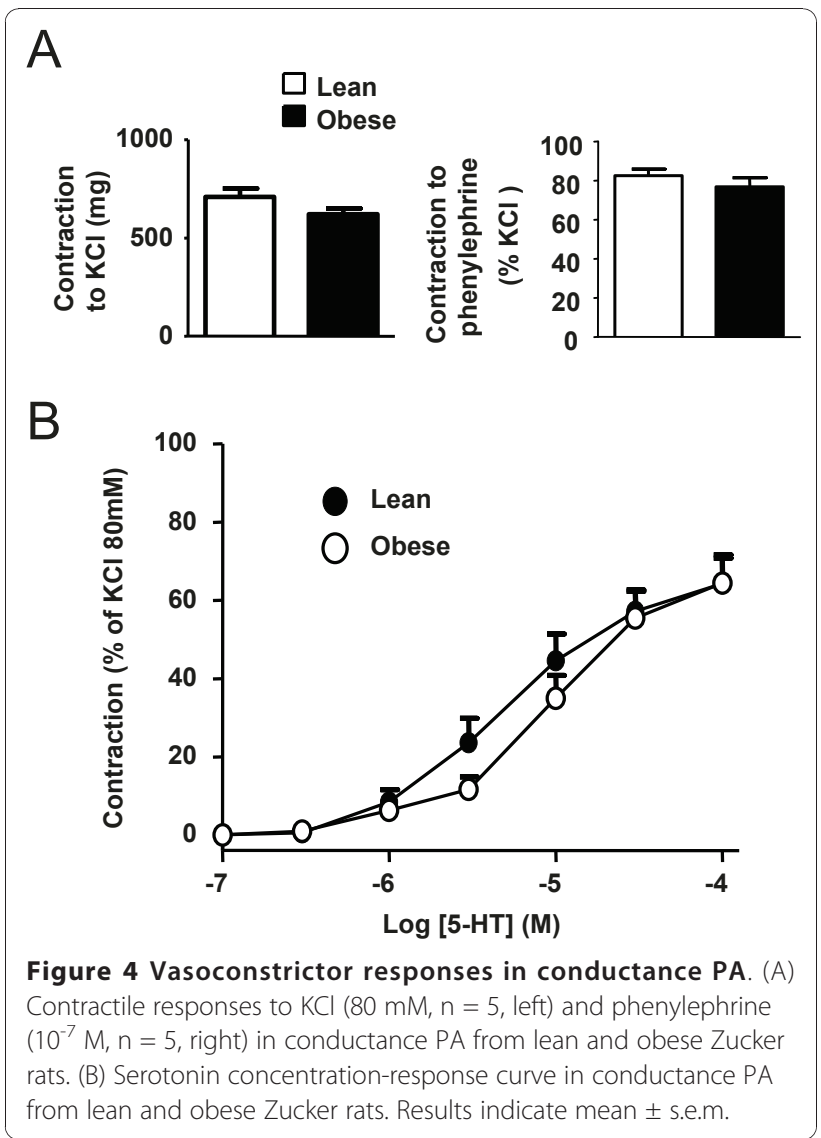

resistance PA from both groups and even when a trend to increased transcription of iNOS mRNA was observed, the difference did not achieve statistical significance (Figure 6C). However, we found a significant increase in iNOS protein expression in resistance pulmonary arteries from obese rats (Figure 6D).

\section{Discussion}

Epidemiological studies show that insulin resistance appears to be more common in pulmonary hypertension than in the general population [18]. Similarly, patients with type II diabetes mellitus have significantly higher prevalence of pulmonary embolism and pulmonary hypertension independent of coronary diseases, hypertension, congestive hearth failure or smoking [19]. Recent data of our group demonstrated a marked endothelial dysfunction in PA characterized by an increase of reactive oxygen species and by an increased expression of $\mathrm{p} 47^{\text {phox }}[8]$ as well as a decreased BMPR2 lung expression together with exaggerated response of PA to 5-HT (authors unpublished observations) in rats treated with streptozotocin as an insulin-dependent diabetes model. Additionally, experimental data demonstrated that $\mathrm{ApoE}^{-1-}$ mice on a high fat diet develop PAH as judged by an elevated right ventricular systolic pressure and augmented RV/(LV $+S)$ relation when compared to controls [21]. The aim of the present study was to further investigate the relationship between insulin resistance and pulmonary hypertension. For this purpose we have used a well established genetic model of obesity and insulin resistance, the obese Zucker rat, characterized by a missense mutation in the leptin receptor [28] and associated with several cardiovascular complications $[22,29]$.

Sustained elevated pulmonary pressure results in compensatory right ventricular hypertrophy and, therefore, the weight or the wall thickness of the right ventricle can be used as an indirect index of pulmonary artery pressure. Increased right ventricular weight compared to the left ventricle plus the septum weight has been described in streptozotocin-induced type 1 diabetes [30] and in insulin resistant ApoE knockout mice [21]. However, we did not find changes in the left or right ventricular wall thickness in obese Zucker rats as compared to lean ones. Fredersdorf et al. also reported similar heart weight in these strains [22]. Additionally, mutations in the BMPR2 or the diminished expression of BMPR2 has been described in lungs from PAH patients

Table 1 Parameters of the concentration-response curve to vasoconstrictor agonists in isolated conductance and resistance PA from lean and obese Zucker rats [means \pm s.e.m. (n)].

\begin{tabular}{|c|c|c|c|c|}
\hline & \multicolumn{2}{|c|}{$E_{\max }(\%$ of $\mathrm{KCl})$} & \multicolumn{2}{|c|}{$\mathrm{pD}_{2}$} \\
\hline & Lean & Obese & Lean & Obese \\
\hline \multicolumn{5}{|l|}{ Conductance PA } \\
\hline Phenylephrine & $82.6 \pm 3.2(5)$ & $83.7 \pm 4.1(5)$ & $8.20 \pm 0.03$ & $8.10 \pm 0.09$ \\
\hline 5-HT & $64.3 \pm 6.5(5)$ & $64.4 \pm 7.2(5)$ & $5.28 \pm 0.13$ & $5.02 \pm 0.11$ \\
\hline$\alpha$-methyl-5-HT & $41.0 \pm 9.5(6)$ & $30.8 \pm 6.8(6)$ & $5.32 \pm 0.13$ & $5.46 \pm 0.12$ \\
\hline \multicolumn{5}{|l|}{ Resistance PA } \\
\hline 5-HT & $69.2 \pm 7.8(6)$ & $33.5 \pm 9.1 *(6)$ & $5.28 \pm 0.10$ & $4.86 \pm 0.06$ ** \\
\hline 5-HT (1400W) & $49 \pm 7(6)$ & $58 \pm 9(6)$ & $5.10 \pm 0.13$ & $5.24 \pm 0.15$ \\
\hline$\alpha$-methyl-5-HT & $33.7 \pm 8.8$ (4) & $9.5 \pm 3.6 *(4)$ & $5.80 \pm 0.11$ & $5.58 \pm 0.10$ \\
\hline
\end{tabular}




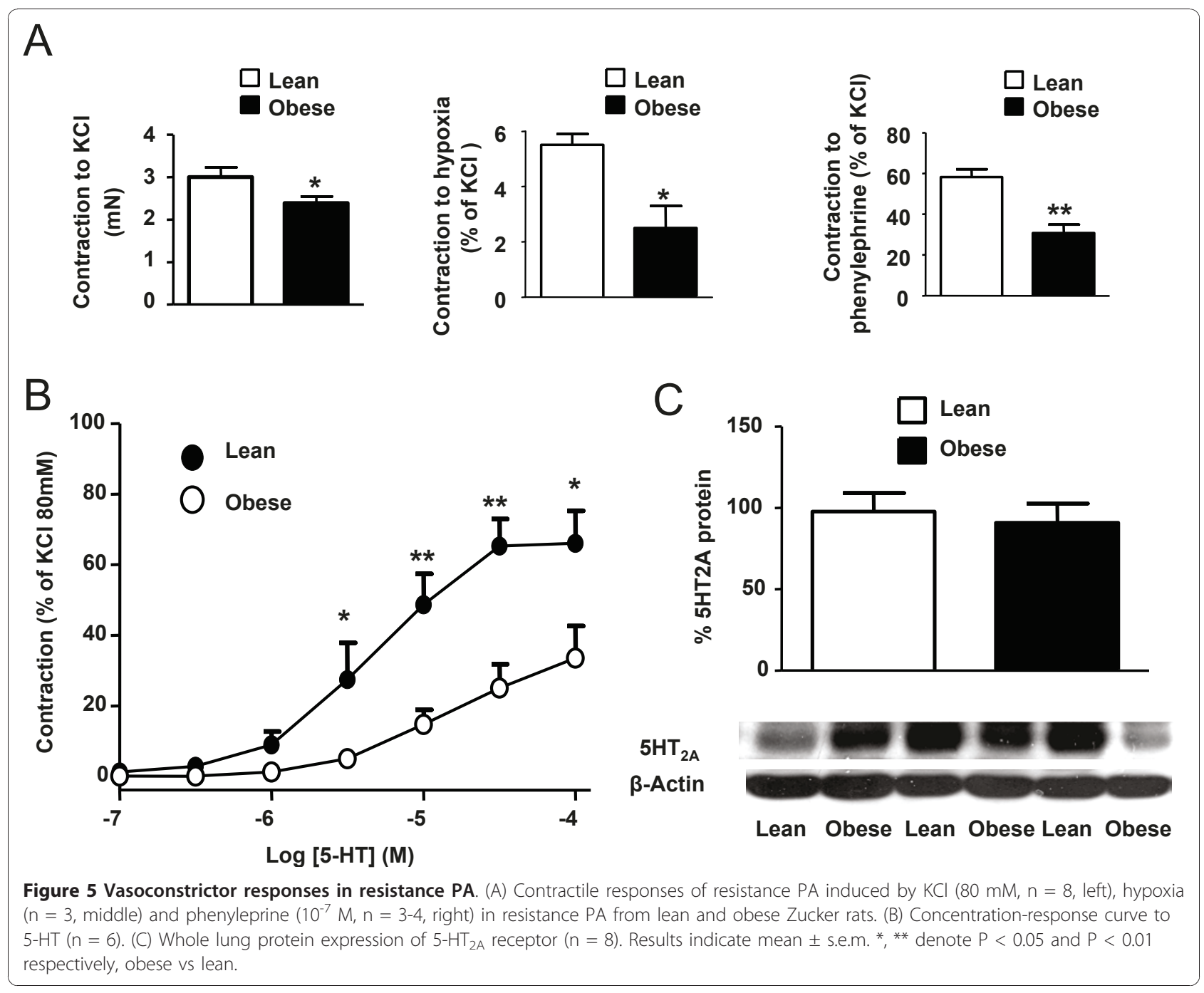

[4] and from rats with monocrotaline- or hypoxiainduced PAH [5-7]. Recently we also found a downregulation in the lung expression of BMPR2 in streptozotocin-treated rats (authors unpublished observations); nonetheless, our RT-PCR analysis revealed no changes in the BMPR2-mRNA levels of obese as compared to lean rats. This was further confirmed by Western blot analysis where the expression of neither BMPR2 nor its heavier precursor (pro-BMPR2) were significantly modified.

PAH has been associated with a decrease in PASMC $\mathrm{K}_{\mathrm{V}}$ currents and with reduced expression of $\mathrm{K}_{\mathrm{V}}$ channels, mainly $\mathrm{K}_{\mathrm{V}} 1.5, \mathrm{~K}_{\mathrm{v}} 3.1$ and $\mathrm{K}_{\mathrm{V}} 2.1$ [14]. $\mathrm{K}_{\mathrm{V}} 1.5$ mRNA and protein expression, $\mathrm{K}_{\mathrm{V}}$ current density as well as the inhibitory effects of hypoxia in freshly isolated PASMC were unchanged in obese as compared to lean rats. Additionally, PASMC from obese rats showed no signs of hypertrophy as indicated by the capacitance data.
Endothelial dysfunction is characterized by a diminished vasodilator response to acetylcholine due to a reduced NO release or increase NO metabolism. Insulin resistant states and diabetes are associated to reduced endothelium-dependent relaxation and linked to cardiovascular events [31-33]. Moreover, endothelial dysfunction is a key factor in the development of retinopathy, nephropathy and atherosclerosis in both type 1 and type 2 diabetes [34,35] and also in PAH [36]. However, endothelial dysfunction is not consistently found in insulin resistance. In Zucker rats, endothelial function was impaired in the aorta and several systemic arteries [37]. In contrast, vascular reactivity and eNOS expression or phosphorylation were unchanged in hindlimb arteries [38]. Moreover, endothelial dysfunction was found in penile arteries but not in coronary arteries from obese Zucker rats in a single study [32], confirming the tissue-dependency of this effect. To our knowledge pulmonary endothelial function has not been 


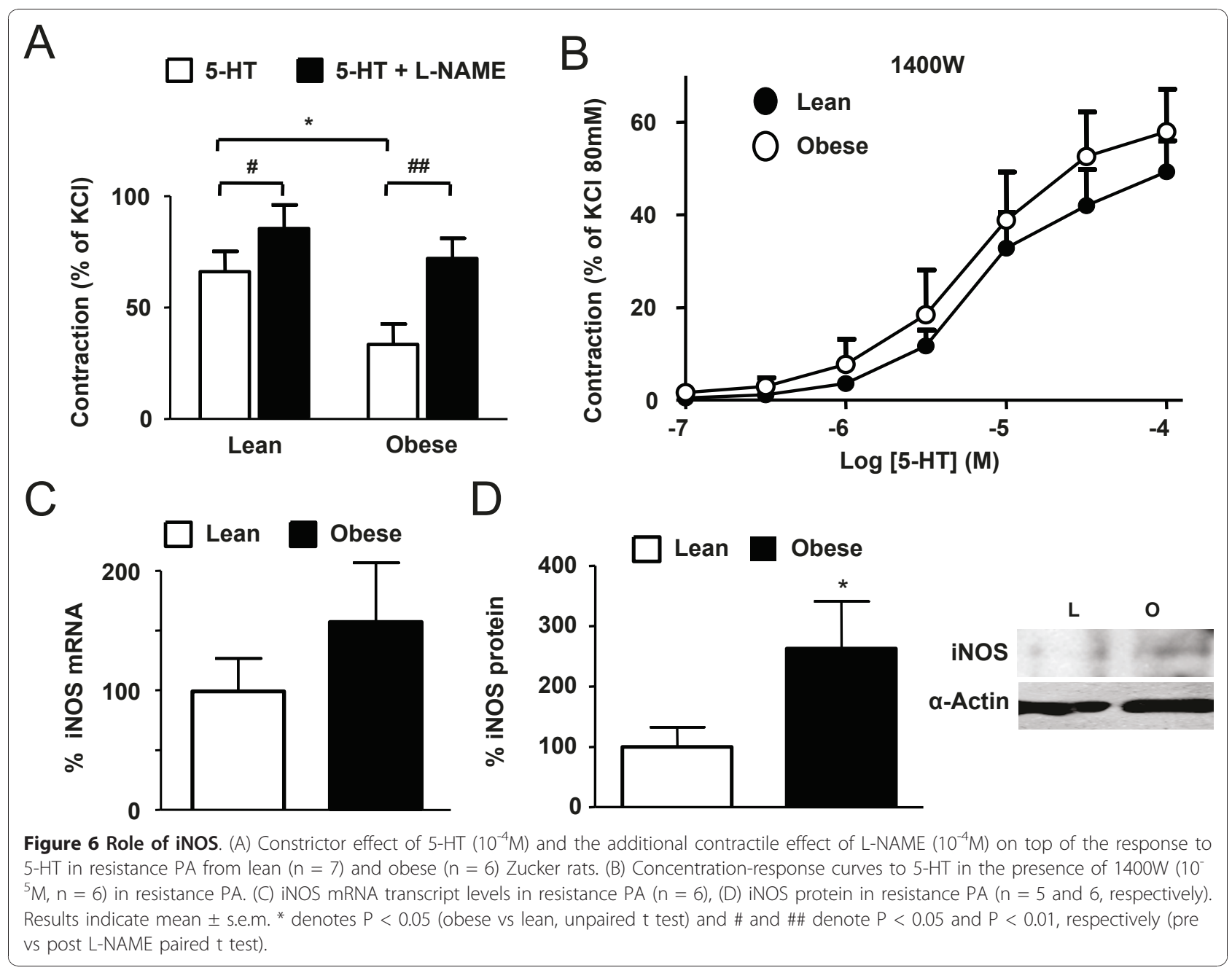

analyzed in the context of insulin resistance. In the present experiments, the ACh-relaxation curve in conductance and resistance PA and the eNOS mRNA and protein expression were similar in obese as compared to lean rats, indicating a preserved PA-endothelial function in this model. However, our group has recently reported endothelial dysfunction in PA of type 1 diabetic rats associated to increased ROS production and increased expression of NADPH [8] as well as hyperresponsiveness to 5-HT.

In contrast to all the above described similarities between obese and lean rats, we found differences in the constrictor response in resistance but not in conductance PA from obese rats. Resistance PA showed diminished contractile responses to hypoxia, phenylephrine, $\mathrm{KCl}$ and $5-\mathrm{HT}$ as compared to lean resistance PA, while similar responses to phenylephrine, $\mathrm{KCl}$ or 5 - $\mathrm{HT}$ were found in conductance PA. In contrast, in a type 1 rat model of diabetes decreased responses were found in conductance but not in small PA [39]. Responses to vasoconstrictors have been also described to be reduced in some systemic beds from obese Zucker rats such as the mesenteric arteries [23] but enhanced in others such as the penile and coronary arteries [32]. Western blot analysis revealed no changes in the whole lung expression of $5-\mathrm{HT}_{2 \mathrm{~A}}$, ruling out that downregulation of 5 $\mathrm{HT}_{2 \mathrm{~A}}$ could be responsible of the reduced response to 5-HT in resistance PA.

Inducible nitric oxide synthase has emerged as a key protein in insulin resistance and obesity. Moreover, iNOS has been directly related to cardiac contractile dysfunction [40] and in vascular complications derived from insulin resistance [41,42]. We found that the contractile response to 5 - HT was increased by the non selective NO synthase inhibitor L-NAME much more effectively in the obese than in the lean rats, suggesting that increased NO synthesis was responsible for the vascular hyporesponsiveness in the obese rats. Furthermore, the incubation with selective iNOS inhibitor $1400 \mathrm{~W}$ restored $5-\mathrm{HT}$ response curve suggesting that iNOS was 
responsible for this exaggerated NO synthesis. Since iNOS activity is primarily regulated at a transcriptional level and that once expressed the enzyme produces large amounts of NO, we investigated iNOS expression levels. The levels of iNOS mRNA tended to be higher in resistance PA from obese rats but differences did not reach statistical significance due to the high variability within our experimental samples. However the protein iNOS expression was significantly higher in obese resistance PA than in lean resistance PA. iNOS upregulation has also been found in other tissues such as the aorta, the visceral adipose tissue and the heart in the Zucker obese rats and other models of insulin resistance $[40,42,43]$. There are a large number of studies showing that increased expression of iNOS induced by lipopolysaccharide (LPS) is accompanied by endothelial dysfunction, as opposed to the present study. Moreover, iNOS gene deletion or pharmacological inhibition prevents LPS-induced endothelial dysfunction suggesting a causeeffect relationship [44]. However, iNOS overexpression induced by LPS is much larger (e.g. > 10 fold increase) than in the present study. More importantly, it is peroxynitrite (and probably not NO itself) produced in the reaction of iNOS-derived NO with superoxide which is responsible for endothelial dysfunction [45]. We have not measured superoxide or peroxynitrite in resistance PA, but the lack of endothelial dysfunction suggests that oxidative stress is not increased in these arteries.

\section{Conclusions}

Herein we characterized for the first time the effects of insulin resistance in the pulmonary circulation of the obese Zucker rats. Some studies have related insulin resistance with $\mathrm{PAH}$ in humans and in other animal models but we did not find any of the characteristic features related with this pathology in the obese Zucker rat at the age of 17-18 weeks. However, this rat strain showed pulmonary vascular hyporesponsiveness in resistance arteries which could be prevented by inhibition of iNOS.

\section{List of abbreviations}

ACh: acetylcholine; BMPR2: bone morphogenetic protein receptor 2; $E_{\text {max: }}$ maximum response; LV: left ventricle; PA: pulmonary arteries; PAH: pulmonary arterial hypertension; PASMC: pulmonary artery smooth muscle cells; $\mathrm{pD}_{2}$ : negative logarithm of the molar concentration that causes $50 \%$ of the maximum response; RV: right ventricle; S: septum.

\section{Acknowledgements}

We thank Bianca Barreira for excellent technical assistance. This work was supported by Ministerio de Ciencia e Innovacion (grants SAF2008-03948 and AGL2007-66108) and Mutua Madrileña.

\section{Authors' contributions}

JM-S performed the Western blots and electrophysiological measurements and wrote the first draft of the manuscript, CM performed the PCRs and vascular reactivity, EM measured hearts and glucose, AC and LM supervised and coordinated the study. FP-V conceived the study and wrote the final manuscript. All authors contributed to the analysis and interpretation of the data. All authors have read and approved the final submission.

\section{Competing interests}

The authors declare that they have no competing interests.

Received: 2 November 2010 Accepted: 22 April 2011

Published: 22 April 2011

\section{References}

1. Morrell NW, Adnot S, Archer SL, Dupuis J, Jones PL, MacLean MR, McMurtry IF, Stenmark KR, Thistlethwaite PA, Weissmann N, et al: Cellular and molecular basis of pulmonary arterial hypertension. J Am Coll Cardiol 2009, 54:S20-31.

2. Cogolludo A, Moreno L, Villamor E: Mechanisms controlling vascular tone in pulmonary arterial hypertension: implications for vasodilator therapy. Pharmacology 2007, 79:65-75.

3. Chan SY, Loscalzo J: Pathogenic mechanisms of pulmonary arterial hypertension. J Mol Cell Cardiol 2008, 44:14-30.

4. Atkinson C, Stewart S, Upton PD, Machado R, Thomson JR, Trembath RC, Morrell NW: Primary pulmonary hypertension is associated with reduced pulmonary vascular expression of type II bone morphogenetic protein receptor. Circulation 2002, 105:1672-1678.

5. Morty RE, Nejman B, Kwapiszewska G, Hecker M, Zakrzewicz A, Kouri FM Peters DM, Dumitrascu R, Seeger W, Knaus P, et al: Dysregulated bone morphogenetic protein signaling in monocrotaline-induced pulmonary arterial hypertension. Arterioscler Thromb Vasc Biol 2007, 27:1072-1078.

6. Takahashi H, Goto N, Kojima Y, Tsuda Y, Morio Y, Muramatsu M, Fukuchi Y: Downregulation of type II bone morphogenetic protein receptor in hypoxic pulmonary hypertension. Am J Physiol Lung Cell Mol Physiol 2006, 290:L450-458.

7. Long L, MacLean MR, Jeffery TK, Morecroft I, Yang X, Rudarakanchana N, Southwood M, James V, Trembath RC, Morrell NW: Serotonin increases susceptibility to pulmonary hypertension in BMPR2-deficient mice. Circ Res 2006, 98:818-827.

8. Lopez-Lopez JG, Moral-Sanz J, Frazziano G, Gomez-Villalobos MJ, FloresHernandez J, Monjaraz E, Cogolludo A, Perez-Vizcaino F: Diabetes induces pulmonary artery endothelial dysfunction by NADPH oxidase induction. Am J Physiol Lung Cell Mol Physiol 2008, 295:L727-732.

9. Rodat L, Savineau JP, Marthan R, Guibert C: Effect of chronic hypoxia on voltage-independent calcium influx activated by $5-\mathrm{HT}$ in rat intrapulmonary arteries. Pflugers Arch 2007, 454:41-51.

10. Csiszar A, Labinskyy N, Olson S, Pinto JT, Gupte S, Wu JM, Hu F, Ballabh P, Podlutsky A, Losonczy G, et al: Resveratrol prevents monocrotalineinduced pulmonary hypertension in rats. Hypertension 2009, 54:668-675.

11. Hironaka E, Hongo M, Sakai A, Mawatari E, Terasawa F, Okumura N, Yamazaki A, Ushiyama Y, Yazaki Y, Kinoshita O: Serotonin receptor antagonist inhibits monocrotaline-induced pulmonary hypertension and prolongs survival in rats. Cardiovasc Res 2003, 60:692-699.

12. Cogolludo A, Perez-Vizcaino F: 5-HT receptors and K(V) channel internalization. Adv Exp Med Biol 2010, 661:391-401.

13. Remillard CV, Tigno DD, Platoshyn O, Burg ED, Brevnova EE, Conger D, Nicholson A, Rana BK, Channick RN, Rubin LJ, et al: Function of Kv1.5 channels and genetic variations of KCNA5 in patients with idiopathic pulmonary arterial hypertension. Am J Physiol Cell Physiol 2007, 292: C1837-1853.

14. Yuan JX, Aldinger AM, Juhaszova M, Wang J, Conte JV Jr, Gaine SP, Orens JB, Rubin LJ: Dysfunctional voltage-gated K+ channels in pulmonary artery smooth muscle cells of patients with primary pulmonary hypertension. Circulation 1998, 98:1400-1406.

15. Kirk EP, Klein S: Pathogenesis and pathophysiology of the cardiometabolic syndrome. J Clin Hypertens (Greenwich) 2009, 11:761-765.

16. Cherian B, Meka N, Katragadda S, Arora R: Therapeutic implications of diabetes in cardiovascular disease. Am J Ther 2009, 16:e51-59.

17. Fouty B: Diabetes and the pulmonary circulation. Am J Physiol Lung Cell Mol Physiol 2008, 295:L725-726.

18. Zamanian RT, Hansmann G, Snook S, Lilienfeld D, Rappaport KM, Reaven GM, Rabinovitch M, Doyle RL: Insulin resistance in pulmonary arterial hypertension. Eur Respir J 2009, 33:318-324. 
19. Movahed MR, Hashemzadeh M, Jamal MM: The prevalence of pulmonary embolism and pulmonary hypertension in patients with type II diabetes mellitus. Chest 2005, 128:3568-3571.

20. Robbins IM, Newman JH, Johnson RF, Hemnes AR, Fremont RD, Piana RN, Zhao DX, Byrne DW: Association of the metabolic syndrome with pulmonary venous hypertension. Chest 2009, 136:31-36.

21. Hansmann G, Wagner RA, Schellong S, Perez VA, Urashima T, Wang L, Sheikh AY, Suen RS, Stewart DJ, Rabinovitch M: Pulmonary arterial hypertension is linked to insulin resistance and reversed by peroxisome proliferator-activated receptor-gamma activation. Circulation 2007, 115:1275-1284

22. Fredersdorf S, Thumann C, Ulucan C, Griese DP, Luchner A, Riegger GA, Kromer EP, Weil J: Myocardial hypertrophy and enhanced left ventricular contractility in Zucker diabetic fatty rats. Cardiovasc Pathol 2004, 13:11-19.

23. Romanko OP, Stepp DW: Reduced constrictor reactivity balances impaired vasodilation in the mesenteric circulation of the obese Zucker rat. Am J Physiol Heart Circ Physiol 2005, 289:H2097-2102.

24. Song D, Yao R, Pang CC: Altered vasodilator role of nitric oxide synthase in the pancreas, heart and brain of rats with spontaneous type 2 diabetes. Eur J Pharmacol 2008, 591:177-181

25. Cogolludo A, Moreno L, Lodi F, Frazziano G, Cobeno L, Tamargo J, PerezVizcaino F: Serotonin inhibits voltage-gated $\mathrm{K}+$ currents in pulmonary artery smooth muscle cells: role of 5 - $\mathrm{HT} 2 \mathrm{~A}$ receptors, caveolin-1, and KV1.5 channel internalization. Circ Res 2006, 98:931-938.

26. Cogolludo A, Moreno L, Frazziano G, Moral-Sanz J, Menendez C, Castaneda J, Gonzalez C, Villamor E, Perez-Vizcaino F: Activation of neutral sphingomyelinase is involved in acute hypoxic pulmonary vasoconstriction. Cardiovasc Res 2009, 82:296-302.

27. Cogolludo A, Moreno L, Lodi F, Tamargo J, Perez-Vizcaino F: Postnatal maturational shift from PKCzeta and voltage-gated K+ channels to RhoA/Rho kinase in pulmonary vasoconstriction. Cardiovasc Res 2005, 66:84-93.

28. Takaya K, Ogawa Y, Isse N, Okazaki T, Satoh N, Masuzaki H, Mori K, Tamura N, Hosoda K, Nakao K: Molecular cloning of rat leptin receptor isoform complementary DNAs-identification of a missense mutation in Zucker fatty $(\mathrm{fa} / \mathrm{fa}$ ) rats. Biochem Biophys Res Commun 1996, 225:75-83.

29. Osmond JM, Mintz JD, Dalton B, Stepp DW: Obesity increases blood pressure, cerebral vascular remodeling, and severity of stroke in the Zucker rat. Hypertension 2009, 53:381-386.

30. Al-Shafei Al, Wise RG, Gresham GA, Bronns G, Carpenter TA, Hall LD, Huang CL: Non-invasive magnetic resonance imaging assessment of myocardial changes and the effects of angiotensin-converting enzyme inhibition in diabetic rats. J Physiol 2002, 538:541-553.

31. Frisbee JC: Reduced nitric oxide bioavailability contributes to skeletal muscle microvessel rarefaction in the metabolic syndrome. Am J Physiol Regul Integr Comp Physiol 2005, 289:R307-R316.

32. Villalba N, Martinez P, Briones AM, Sanchez A, Salaices M, Garcia-Sacristan A, Hernandez M, Benedito S, Prieto D: Differential structural and functional changes in penile and coronary arteries from obese Zucker rats. Am J Physiol Heart Circ Physiol 2009, 297:H696-707.

33. Serpillon S, Floyd BC, Gupte RS, George S, Kozicky M, Neito V, Recchia F, Stanley W, Wolin MS, Gupte SA: Superoxide production by NAD(P)H oxidase and mitochondria is increased in genetically obese and hyperglycemic rat heart and aorta before the development of cardiac dysfunction. The role of glucose-6-phosphate dehydrogenase-derived NADPH. Am J Physiol Heart Circ Physiol 2009, 297:H153-162.

34. Stehouwer CD, Lambert J, Donker AJ, van Hinsbergh WW: Endothelial dysfunction and pathogenesis of diabetic angiopathy. Cardiovasc Res 1997, 34:55-68.

35. Jay D, Hitomi $H$, Griendling KK: Oxidative stress and diabetic cardiovascular complications. Free Radic Biol Med 2006, 40:183-192.

36. Coggins MP, Bloch KD: Nitric oxide in the pulmonary vasculature. Arterioscler Thromb Vasc Biol 2007, 27:1877-1885.

37. Toblli J, Cao G, Rivas C, Munoz M, Giani J, Dominici F, Angerosa M: Cardiovascular protective effects of nebivolol in Zucker diabetic fatty rats. J Hypertens 2010, 28:1007-1019.

38. Fulton D, Harris MB, Kemp BE, Venema RC, Marrero MB, Stepp DW: Insulin resistance does not diminish eNOS expression, phosphorylation, or binding to HSP-90. Am J Physiol Heart Circ Physiol 2004, 287:H2384-2393.
39. Gurney AM, Howarth FC: Effects of streptozotocin-induced diabetes on the pharmacology of rat conduit and resistance intrapulmonary arteries. Cardiovasc Diabetol 2009, 8:4

40. Song D, Kuo KH, Yao R, Hutchings SR, Pang CC: Inducible nitric oxide synthase depresses cardiac contractile function in Zucker diabetic fatty rats. Eur J Pharmacol 2008, 579:253-259.

41. Gunnett CA, Heistad DD, Faraci FM: Gene-targeted mice reveal a critical role for inducible nitric oxide synthase in vascular dysfunction during diabetes. Stroke 2003, 34:2970-2974

42. Noronha BT, Li JM, Wheatcroft SB, Shah AM, Kearney MT: Inducible nitric oxide synthase has divergent effects on vascular and metabolic function in obesity. Diabetes 2005, 54:1082-1089.

43. Rivera L, Moron R, Sanchez M, Zarzuelo A, Galisteo M: Quercetin ameliorates metabolic syndrome and improves the inflammatory status in obese Zucker rats. Obesity (Silver Spring) 2008, 16:2081-2087.

44. Chauhan SD, Seggara G, Vo PA, Macallister RJ, Hobbs AJ, Ahluwalia A: Protection against lipopolysaccharide-induced endothelial dysfunction in resistance and conduit vasculature of iNOS knockout mice. FASEB J 2003, 17:773-775.

45. Cuzzocrea S, Mazzon E, Di Paola R, Esposito E, Macarthur H, Matuschak GM, Salvemini D: A role for nitric oxide-mediated peroxynitrite formation in a model of endotoxin-induced shock. J Pharmacol Exp Ther 2006, 319:73-81.

doi:10.1186/1465-9921-12-51

Cite this article as: Moral-Sanz et al:: Pulmonary arterial dysfunction in insulin resistant obese Zucker rats. Respiratory Research 2011 12:51.

\section{Submit your next manuscript to BioMed Central and take full advantage of:}

- Convenient online submission

- Thorough peer review

- No space constraints or color figure charges

- Immediate publication on acceptance

- Inclusion in PubMed, CAS, Scopus and Google Scholar

- Research which is freely available for redistribution

Submit your manuscript at www.biomedcentral.com/submit
Ciomed Central 